\begin{tabular}{|c|c|c|c|c|c|c|}
\hline \multirow{4}{*}{ Impact Factor: } & ISRA (India) & $=3.117$ & SIS (USA) & $=0.912$ & ICV (Poland) & $=6.630$ \\
\hline & ISI (Dubai, UAE & $=0.829$ & РИНЦ (Russia) & $=0.156$ & PIF (India) & $=1.940$ \\
\hline & GIF (Australia) & $=0.564$ & ESJI (KZ) & $=8.716$ & IBI (India) & $=4.260$ \\
\hline & JIF & $=1.500$ & SJIF (Morocco) & $=5.667$ & OAJI (USA) & $=0.350$ \\
\hline
\end{tabular}

SOI: $1.1 /$ TAS
International Scientific Journal
Theoretical \& Applied Science
$\begin{array}{lll}\text { p-ISSN: } 2308-4944 \text { (print) } & \text { e-ISSN: } 2409-0085 \text { (online) } \\ \text { Year: } 2019 \quad \text { Issue: } 06 \quad \text { Volume: } 74 \\ \text { Published: } 15.06 .2019 \quad \text { http://T-Science.org }\end{array}$

SECTION 11. Biology. Ecology. Veterinary.

UDC 556.556 (575.22); (235.216.1)
QR - Issue

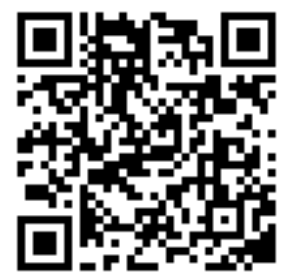

QR - Article

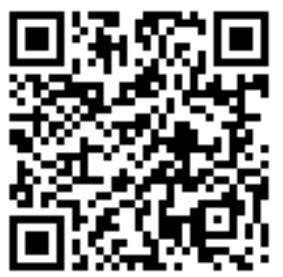

Lola Toktomuratovna Kamilova Kyrgyz-Uzbek University Candidate of Geographical Sciences, head of the Department of " Geography and General Ecology" Naturally Faculty of Education, Osh, Kyrgyz Republic

\title{
ECOLOGICAL CONDITION OF SOILS AT THE STAGE OF ECONOMIC DEVELOPMENT OF KYRGYZSTAN
}

Abstract: The research paper looks at the basins of northern flank of the Alai mountain ridge and geographical principles of glacial flow distribution. Glacial flow is estimated on the basis of genetic division of flow hydrograph. Glacial flow changes are revealed by physiographic conditions.

Key words: mountain, valleys, climate, hygrophilous vegetation, river.

Language: English

Citation: Kamilova, L. T. (2019). Ecological condition of soils at the stage of economic development of Kyrgyzstan. ISJ Theoretical \& Applied Science, 06 (74), 227-229.

Soi: http://s-o-i.org/1.1/TAS-06-74-25 Doi: crossef https://dx.doi.org/10.15863/TAS.2019.06.74.25

\section{Introduction}

The Alai mountain ridge is situated in the South of Osh and Batken regions and covered by the Alai mountain system. This high-mountain ridge, having latitudinal strike and bounding the Fergana basin from the South, separates the Fergana and Alai valleys. One of the highest passes of Kyrgyzstan - Taldyk at a height of 3615 metres above the sea level (m.a.s.l.), is situated on the Eastern part of the Alai mountain ridge. The main prongs are Kollektor ridge, Kichi-Alai ridge, Ak-Ter ridge and the ridge named after academician Adyshev.

The length of the mountain ridge is about 350 kms., maximal width - 35-40 kms., average height 4450 m.a.s.l. High altitudes are fixed on the Western part, where the ridge is covered by eternal snows and glaciers. The maximal height of the Alai mountain ridge is 5539 m.a.s.l. (Tamdykul peak).

The distinctive feature of Northern side of the Alai mountain ridge from other ridges of Tien Shan is that humid air masses are coming parallel to the Alai mountain ridge, like sliding without interception downhill, not going up. As a result of heightening, an arid climate occurs on the Northern side; it creates adverse conditions for growth of hydrophilous vegetation.

Depending on the relief form and the height of the locality the date of ascertainment of a hard snow mantle between the date of failure (50\% of provision) is 76 days at the height of 1500 metres to 178 days at the height of 3155 metres, and the changeability of dates of a hard snow mantle failure is rather intensive, as during the vegetation period there is less precipitation.

\section{Materials and Methods}

The number of days with snow mantle depends upon the height of the locality (see Pic. 1, 2), and the snow mantle depends on density. The thermal conductivity of the water and water reserve in the snow mantle change depending on the density, that is of great agricultural significance; it is also important for flow accounting, etc.

The rivers flowing down from the northern flank of the Alai mountain ridge belong to glacier and snow supply with ground recharge. This basin due to the catchment area equals to $15 \%$ of the whole territory of the republic. The most large rivers of the basin are the River Kurshab, the Ak-Bura river, the Aravan-Sai, the Isfairam-Sai and Shahimardan. For these rivers a summer heavy flow is characteristic. It is formed of melting high mountain snow and ice. Degree of icing of river basins depends on condition of their damping, characteristics of height and morph metric peculiarities. 


\begin{tabular}{llllll} 
& ISRA (India) $=\mathbf{3 . 1 1 7}$ & SIS (USA) & $=\mathbf{0 . 9 1 2}$ & ICV (Poland) & $=\mathbf{6 . 6 3 0}$ \\
Impact Factor: & ISI (Dubai, UAE) $=\mathbf{0 . 8 2 9}$ & PUHL (Russia) $=\mathbf{0 . 1 5 6}$ & PIF (India) & $=\mathbf{1 . 9 4 0}$ \\
& GIF (Australia) $=\mathbf{0 . 5 6 4}$ & ESJI (KZ) & $=\mathbf{8 . 7 1 6}$ & IBI (India) & $=\mathbf{4 . 2 6 0}$ \\
& JIF & $\mathbf{1 . 5 0 0}$ & SJIF (Morocco) $=\mathbf{5 . 6 6 7}$ & OAJI (USA) & $\mathbf{0 . 3 5 0}$ \\
\hline
\end{tabular}

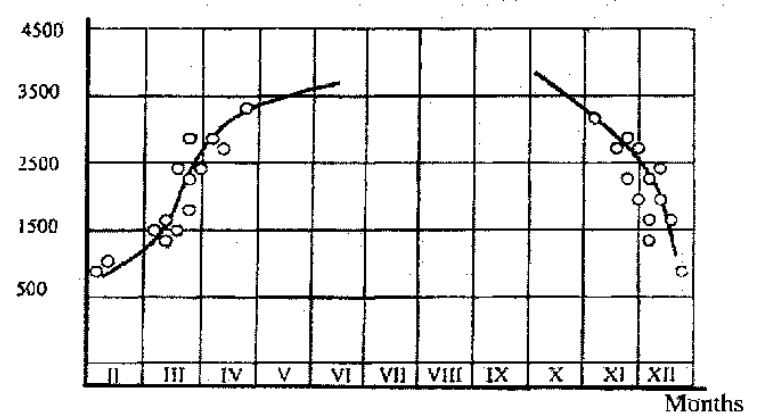

Pic. 1. Relation of destruction dates and establishment of snow cover to height.

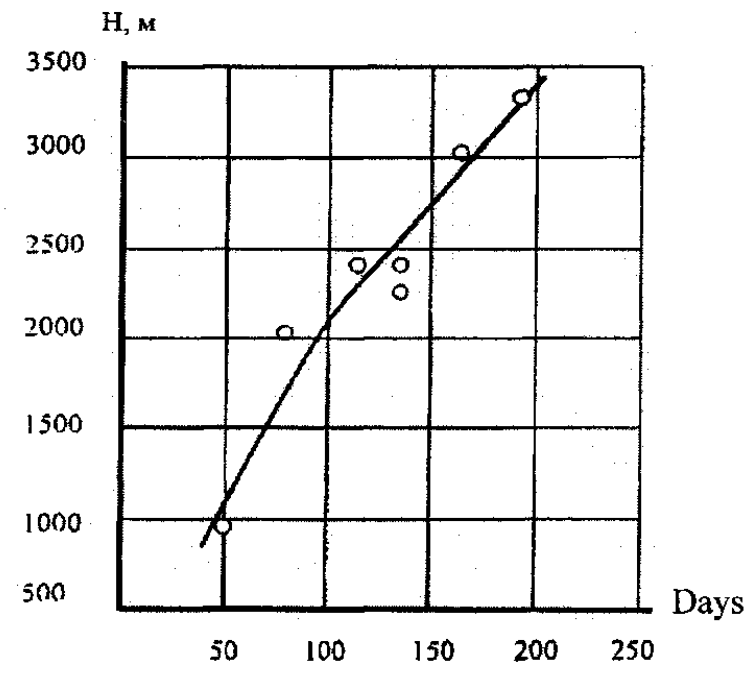

Pic. 2. Relation of days with snow cover to height.

On the flanks of the Alai mountain ridge the largest sources of icing are located in the basins of the rivers of Sokh, the Isfairam-Sai and the Ak-Bura River. In the basins of rivers area of icing fluctuates from 3 to $9 \%$.

To learn constituent elements of water balance we have divided the whole river flow into surface and underground constituents, and water discharge on evaporation and holard damping.

In the surface flow we have identified snow and ice constituents. We have used genetic partition of flow hydrograph as a major method. There has been partition of river flow hydrograph, on which balance accounts have been done.

\section{Conclusion}

On 10 rivers of the region under consideration, where we have data on river flows (Table), we have made 40 hydrographs. Analysis of these data showed us that a hard snow mantle failure on

the Alai mountain ridge at glacial height average of $3500-4000 \mathrm{~m}$. takes place during the third decade of July.
At partition of flow hydrographs we have used data for the years $25 \%, 50 \%, 75 \%$ of provision, as the assessment made by A. A. Ergeshov, I. D. Tsigelnaya, M. A. Muzakeev (1992)/108, I.V. Pylev (1980) show that at such samplings for identification of constituents the error in accounts is not more than $9 \%$.

Snow flow on the northern flanks of the Alai mountain ridge is not big - from 32 to $179 \mathrm{~mm}$., and in average it makes $70-75 \mathrm{~mm}$. It is connected with small snow mantle. In relative values, snow flow of is $11 \%$ in the basins of the Isfairam-Sai river and up to $39 \%$ in the basins of the river Karakol.

Ice constituent of the river flow is formed high in the mountains. Degree of icing depends on spreading surface and morphometric peculiarities; it tends to spread from West to East. The area of icing in the basins of the river Sokh is 4-6\%, river Aravan-Sai - 9\%, Ak-Bura - 2-4\%. Glacial flow part changes from 15 up to $44 \%$. In the ranges of the mountain river outgo the glacial flow part is $25 \%$, and at ranges of glacier tongues this part comes up to $75 \%$. 


\begin{tabular}{|c|c|c|c|c|c|c|}
\hline \multirow{4}{*}{ Impact Factor: } & ISRA (India) & $=3.117$ & SIS (USA) & $=0.912$ & ICV (Poland) & $=6.630$ \\
\hline & ISI (Dubai, UAE & $=0.829$ & РИНЦ (Russi: & $=0.156$ & PIF (India) & $=1.940$ \\
\hline & GIF (Australia) & $=0.564$ & ESJI (KZ) & $=8.716$ & IBI (India) & $=4.260$ \\
\hline & JIF & $=1.500$ & SJIF (Moroce & $=5.667$ & OAJI (USA) & $=0.350$ \\
\hline
\end{tabular}

\section{References:}

1. Ergeshov, A, Tsigelnaya, I. D., \& Muzakeev, M. A. (1992). Water balance of Kyrgyzstan. (p.152). Bishkek: Ilim.

2. (1987). State water cadastre. Part 1. Series 3. Long-term data on regime and resources of surface land waters. Part 1, 2. Volume XI. Kyrgyz SSR. Leningrad: Gidrometeoizdat.

3. Konovalov, V. G. (1972). Ablation of glaciers in Central Asia. (p.158). Leningrad: Gidrometeoizdat.

4. Gerasimov, I. P. (1948). O tipah pochv gornyh stran i vertikal'noj zonal'nosti. Pochvovedenie, № 11, pp.661-669.

5. Kochurov, B. I. (1999). Geojekologija: jekodiagnostika i jekologo-hozjajstvennyj balans territorij. (p.154). Smolensk: SGU.
6. Kochurov, B. I. (1997). Geografija jekologicheskih situacij (jekodiagnostika territorij). (p.156). Moscow: IG RAN.

7. (1998). Kyrgyzskaja Respublika: "Gosudarstvennaja programma po ohrane okruzhajushhej sredy $i$ racional'nomu ispol'zovaniju prirodnyh resursov v Kyrgyzskoj Respubliki 2006-2011 gg.". Bishkek.

8. Mamytov, A. M. (1982). Pochvy gor Srednej Azii $i$ Juzhnogo Kazahstana. (p.250). Frunze: Ilim.

9. Romashkevich, A. I. (1988). Gornoe pochvoobrazovanie $i$ geomorfologicheskie processy. (p.150). Moscow: Nauka. 